Journal of the Geological Society

Magmatism associated with Gondwanaland rifting and Neo-Tethyan oceanic basin development: evidence from the Mamonia Complex, SW Cyprus

G.H.-N. CHAN, J. MALPAS, C. XENOPHONTOS and C.-H. LO

Journal of the Geological Society 2008; v. 165; p. 699-709

doi:10.1144/0016-76492007-050

Email alerting click here to receive free email alerts when new articles cite this article

service

Permission click here to seek permission to re-use all or part of this article

request

Subscribe click here to subscribe to Journal of the Geological Society or the Lyell Collection

\title{
Notes
}

Downloaded by National Taiwan University on 15 September 2009 


\title{
Magmatism associated with Gondwanaland rifting and Neo-Tethyan oceanic basin development: evidence from the Mamonia Complex, SW Cyprus
}

\author{
G. H.-N. CHAN ${ }^{1,2}$, J. MALPAS ${ }^{1}$, C. XENOPHONTOS ${ }^{1} \&$ C.-H. LO ${ }^{3}$ \\ ${ }^{1}$ Department of Earth Sciences, The University of Hong Kong, Pokfulam Road, Hong Kong, China \\ ${ }^{2}$ Present address: Department of Earth Sciences, Oxford University, Parks Road, Oxford OX1 3PR, UK \\ (e-mail: gavin.chan@earth.ox.ac.uk) \\ ${ }^{3}$ Department of Geosciences, National Taiwan University, 1 Roosevelt Road Section 4, Taipei 106, Taiwan
}

\begin{abstract}
Volcanic and intrusive rocks of the Dhiarizos Group, occurring within the Mamonia Complex of SW Cyprus, comprise mainly tholeiitic basalts, ocean island tholeiites (OIT) and other alkalic varieties, with minor alkaline lamprophyre intrusive rocks. These rocks were highly tectonized and dismembered during the collision with the Troodos oceanic lithosphere. Trace element data for the most primitive mafic igneous rock samples suggest that the tholeiitic basalts are derived from a depleted mantle source whereas the OIT and the alkalic basalts originated from variable degrees of partial melting of a spinel peridotite mantle. Alkaline lamprophyres are products of a small degree of partial melting of a deep-seated garnet lherzolite. The bulk of the tholeiites and alkalic varieties are Late Triassic in age and are interpreted as having formed during NeoTethyan sea-floor spreading and associated seamount volcanism. Amphibole separates from a lamprophyre intrusion have ${ }^{40} \mathrm{Ar}-{ }^{39} \mathrm{Ar}$ ages of $140.7 \pm 0.4 \mathrm{Ma}$. In this paper, we report for the first time an Early Cretaceous alkaline lamprophyric magmatism, which is probably associated with a renewed episode of Gondwanaland rifting. These results show that the development of the Neo-Tethyan oceanic basin in the Eastern Mediterranean was largely controlled by a two-phase rifting-drifting process.
\end{abstract}

The easternmost Mediterranean Sea and surrounding landmasses represent remnants of a southern Neo-Tethyan oceanic basin (Fig. 1) (Le Pichon 1982; Dilek \& Moores 1990; Robertson 1998). From the Permo-Triassic to the Cretaceous, the oceanic basin experienced a number of episodes of rifting, subsidence and sea-floor spreading. This led to the formation of a passive continental margin along the northern edge of Gondwanaland, accompanied by detachment and northward drifting of microcontinental blocks. Studies of magmatic rocks play an important role in the formulation of these interpretations.

The first indication of rift-related magmatism is in the Antalya Complex of SW Turkey and occurred during Late Triassic time. Extrusive rocks exhibit geochemical signatures transitional between within-plate basalts (WPB) and mid-ocean ridge basalts (MORB) and are interbedded with shallow-water sediments (Robertson \& Woodcock 1979; Juteau 1980; Robertson \& Waldron 1990; Dilek \& Rowland 1993). In NW Syria, Late Triassic WPB interbedded with redeposited carbonates are known from the Baer-Bassit mélange (Parrot 1977; DelauneMayere 1984; Al-Riyami \& Robertson 2002). Further to the east, in northern Israel, Early Jurassic rift-related volcanic rocks have also been recovered from subsurface samples (e.g. Kohn et al. 1993). Within the Mamonia Complex of SW Cyprus, MORB and subordinate WPB-type volcanic rocks of similar age are also present (Malpas et al. 1993). These rocks are envisaged as being related to rifting (Lapierre 1968, 1975; Lapierre \& Rocci 1976; Swarbrick 1980), sea-floor spreading (Malpas et al. 1993) or within-plate oceanic island volcanism (Lapierre et al. 2007). It is uncertain whether the Late Triassic spreading extended throughout the Jurassic and into the Early Cretaceous until the formation of suprasubduction-zone (SSZ) ophiolites (e.g. the Troodos ophiolite) in the region in the Late Cretaceous. The second phase of magmatism occurred in the Late Jurassic-Early Cretaceous interval. In the Antalya Complex of SW Turkey, MORB-type volcanism of Early Cretaceous age associated with radiolarian cherts is documented (Robertson \& Woodcock 1982; Yilmaz 1984; Robertson \& Waldron 1990; Dilek \& Rowland 1993). Early Cretaceous WPB-type volcanic rocks interbedded with radiolarian cherts and volcaniclastic sediments have also been identified in the Baer-Bassit mélange of NW Syria (Parrot 1977; Delaune-Mayere 1984; Al-Riyami \& Robertson 2002; Al-Riyami et al. 2002). In the Levant, extensive WPB-type magmatic rocks are known from outcrops and subsurface samples, extending from Israel through Jordan and Lebanon to central Syria. These rocks are associated with shallow-water sediments typical of a continental shelf setting and are thought to be related to either rifting (Dercourt et al. 1986; Laws \& Wilson 1997) or hotspot activity (Garfunkel 1989, 1992). No Early Cretaceous magmatic rocks have been found in the Mamonia Complex of SW Cyprus, although the presence of hydrothermal manganiferous deposits of this age might indicate coeval volcanism (Robertson \& Boyle 1983).

In this paper, we describe some rare Early Cretaceous lamprophyres as well as Late Triassic tholeiites and alkalic basalts from the Mamonia Complex of SW Cyprus. We infer their origin and tectonic setting using major and trace element chemistry and their time of formation using ${ }^{40} \mathrm{Ar}-{ }^{39} \mathrm{Ar}$ geochronology. We then discuss the tectonic significance of these igneous rocks.

\section{Regional setting}

The eastern and southern margins of the southern Neo-Tethyan oceanic basin are preserved today along the Levant and NE African margin. To the north, the margin has been modified by plate convergence, the relicts of which are preserved in the 


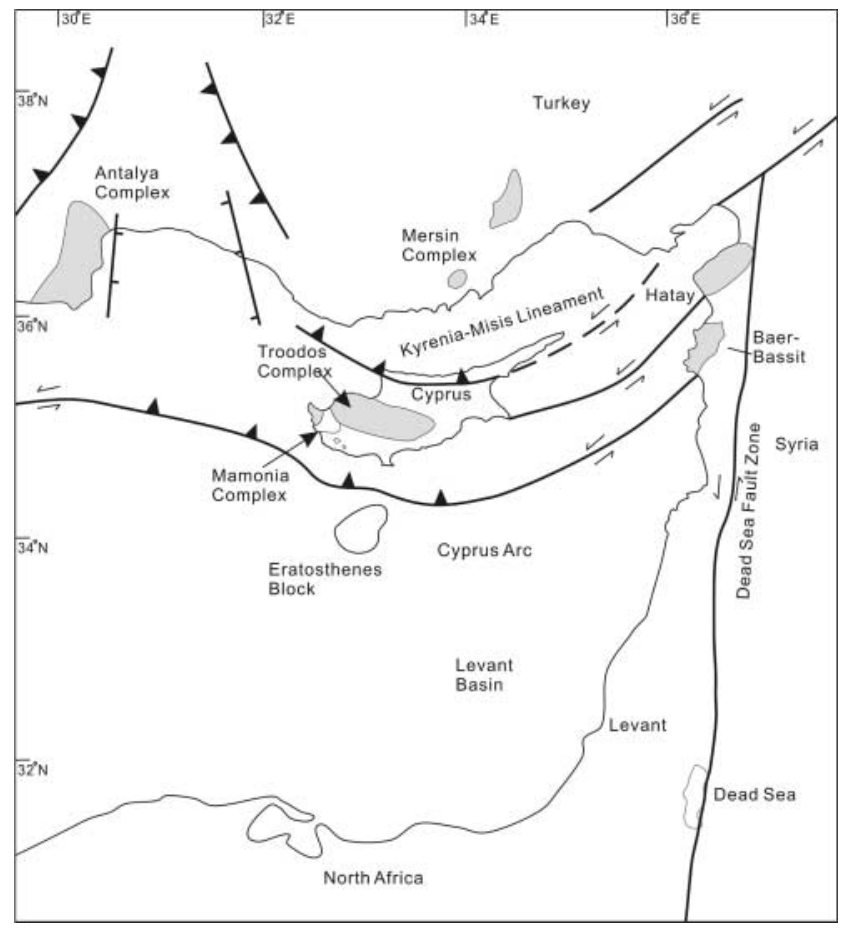

Fig. 1. Tectonic map of the Eastern Mediterranean, showing the main structural domains and elements. Shaded regions represent ophiolites.

Mamonia Complex of SW Cyprus and the Antalya Complex of SW Turkey. The centre of the Neo-Tethyan oceanic basin is occupied by the Levant basin, which comprises transitional to oceanic lithosphere, and includes a continental fragment, the Eratosthenes Block (Ben-Avraham et al. 1976; Woodside 1977; Markis et al. 1983; Robertson \& Mart 1998). The plate boundary between Africa and Eurasia is marked by the active Cyprus Trench, situated between the Eratosthenes Block and Cyprus (Robertson et al. 1995; Papazachos \& Papaioannou 1999).

As indicated by geophysical data, the Levant basin is covered by a thick succession of sediments (more than $12-14 \mathrm{~km}$ in thickness) capping a $8-10 \mathrm{~km}$ thick basement. Seismic data show a high-velocity layer beneath the sediments, interpreted as oceanic crust (Markis et al. 1983; Ben-Avraham et al. 2002). No samples have ever been obtained from the oceanic basement to accurately constrain its age, but on the basis of regional geology, a Cretaceous (Dercourt et al. 1986; Ben-Avraham 1989; Laws \& Wilson 1997) or Triassic (Garfunkel 1998) age has been inferred for the unit. Models constructed from a combination of seismic, magnetic and gravity data imply that the basement of the Levant basin is reversely magnetized and therefore could have formed during either the Early Cretaceous or Early Jurassic period of reversed polarity (Ben-Avraham et al. 2002). The age of the unit has further been constrained from heat flow measurements, which yield an average age of $125 \mathrm{Ma}$, Early Cretaceous (Verzhbitsky 1996).

\section{Geological characteristic of the Mamonia Complex}

In SW Cyprus, the Mamonia Complex is the highly tectonized and collapsed passive margin sequence of a proposed microcontinental block (Robertson \& Woodcock 1979). As a result of microplate collision, the Mamonia Complex has been juxtaposed with the Late Cretaceous SSZ Troodos oceanic lithosphere (Robertson \& Woodcock 1979; Swarbrick 1980, 1993; Robertson 1990; Malpas et al. 1993; Bailey et al. 2000) (Fig. 2). The contact between these terranes is highly deformed and the suture is now essentially represented by a mélange zone. Apart from several erosional windows, the mélange is covered by Maastrichtian debris-flow deposits of the Kathikas Formation and Tertiary chalks of the Lefkara and Pachna Formations, and subsequent sediments (Robertson \& Woodcock 1979; Swarbrick \& Robertson 1980). The Mamonia Complex can be divided into two major units, the Dhiarizos and Ayios Photios Groups, the latter in a low-angle thrust contact with the former (Swarbrick \& Robertson 1980) (Fig. 3).

The Ayios Photios Group rocks occur as disrupted thrust sheets and as blocks in the tectonic mélange, generally within a sedimentary matrix (Swarbrick \& Robertson 1980). Following the early work of Ealey \& Knox (1975), the sedimentary sequences were logged locally and correlated to produce an overall composite succession (Robertson \& Woodcock 1979). The stratigraphic nomenclature was subsequently formalized by Swarbrick \& Robertson (1980). The Ayios Photios Group is made up of Late Triassic sandstone turbidites of the Vlambouros

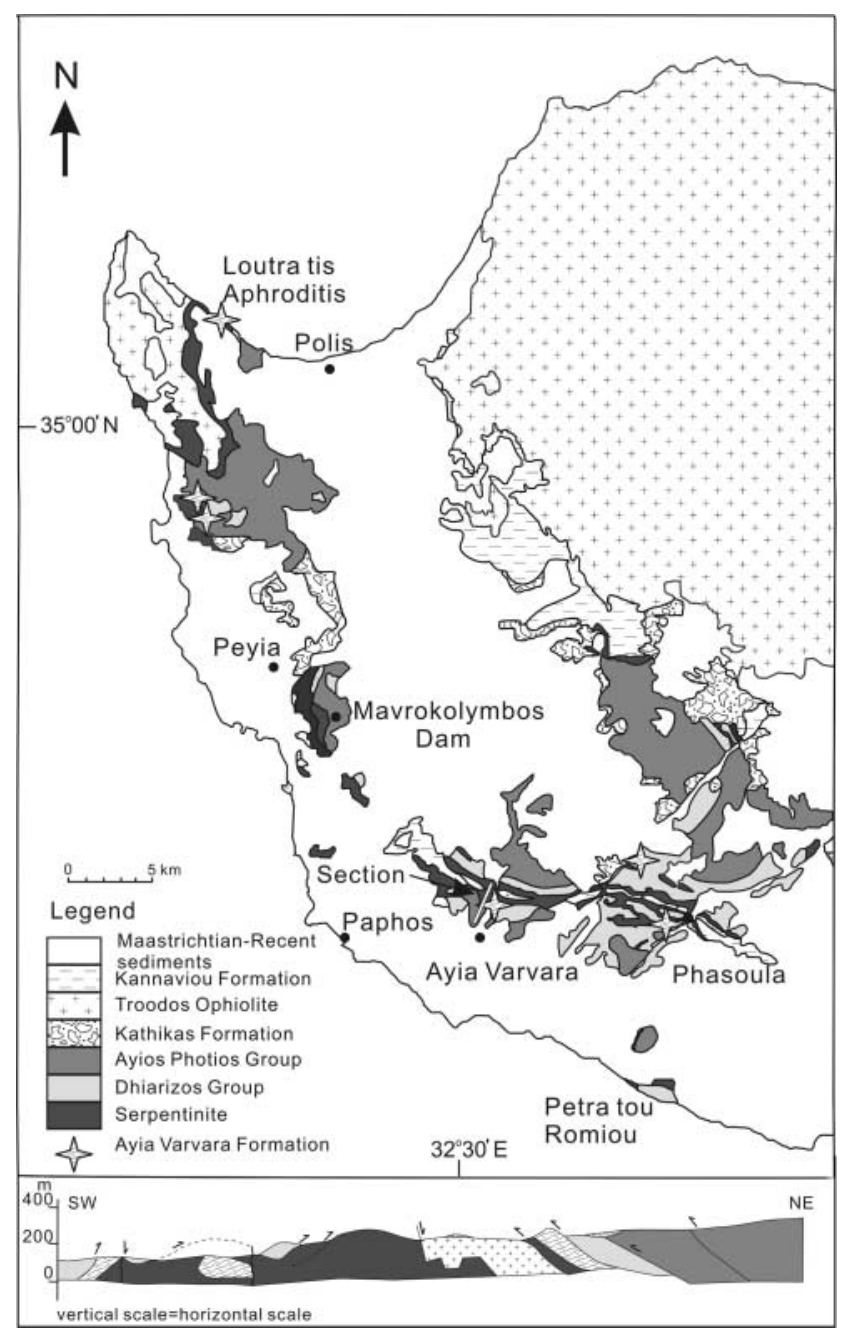

Fig. 2. Simplified geological map of SW Cyprus, after Swarbrick (1980) and Malpas \& Xenophontos (1999). 


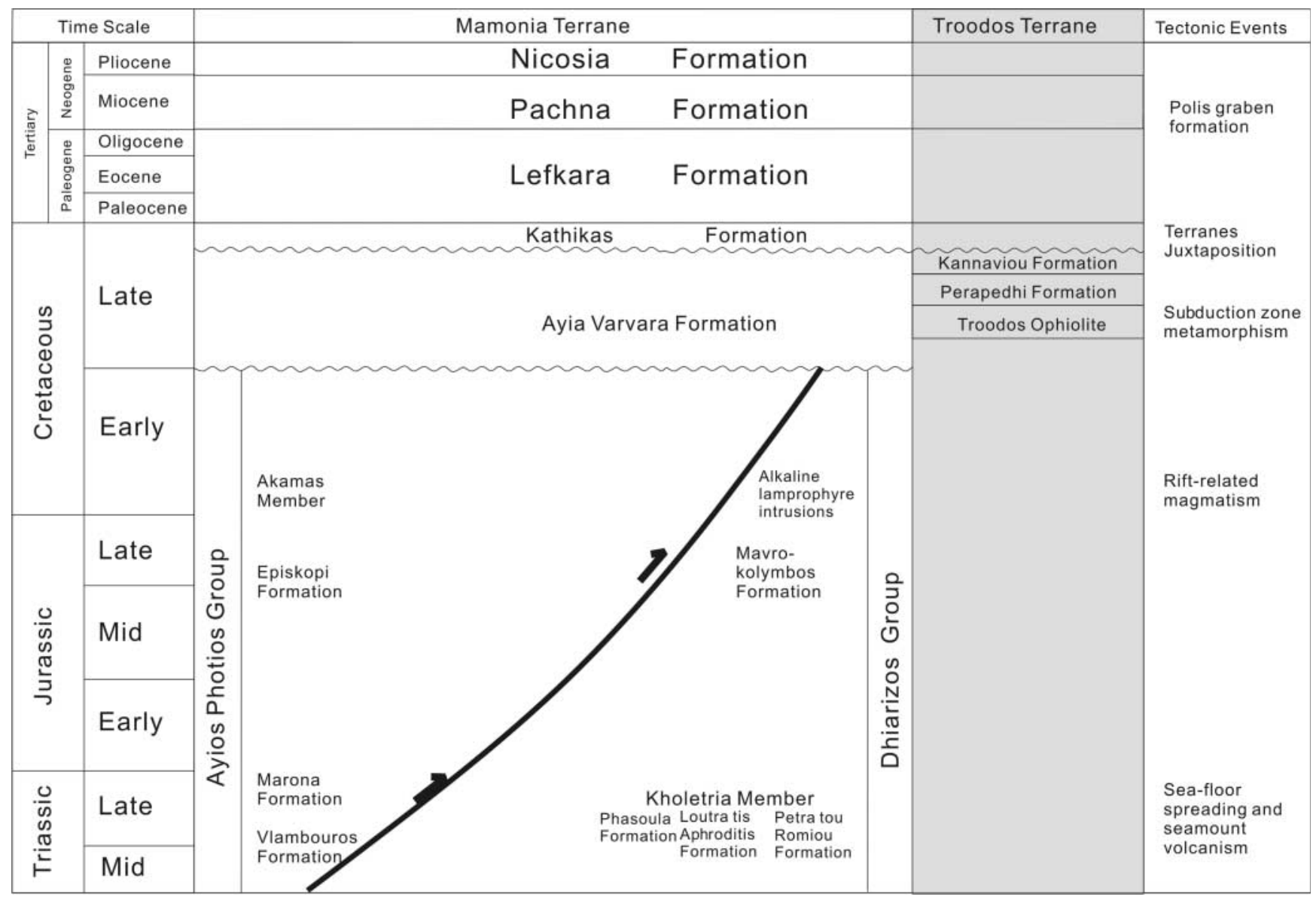

Fig. 3. Tectonostratigraphy of SW Cyprus, after Malpas et al. (1993) and current study.

Formation and local hemipelagic limestones of the Marona Formation, which in turn are overlain by Mid-Jurassic-Early Cretaceous reworked shallow-water limestones, sandstone turbidites, radiolarian mudstones, radiolarites and hydrothermalrelated manganiferous siltstones of the Episkopi Formation. These pass into an important interval of Early Cretaceous quartzose sandstones (Akamas Member). Much of the Ayios Photios Group thus represents a disrupted deep-water passive margin sequence, and proximal slope and shelf deposits and continental basement are notably absent (Robertson \& Woodcock 1979).

Fragments of the Troodos ophiolite including pillow lavas, gabbros and serpentinites and their sedimentary cover also form part of the mélange. The cover includes examples of umbers of the Perapedhi Formation and volcaniclastic rocks of the Kannaviou Formation (Robertson 1977; Urquhart \& Banner 1994). Greenschist- to amphibolite-facies metamorphic rocks of the Ayia Varvara Formation also occur as blocks that are ubiquitously associated with serpentinites in the mélange. These metamorphic rocks record ${ }^{40} \mathrm{Ar}-{ }^{39} \mathrm{Ar}$ ages of $90-75 \mathrm{Ma}$ and are believed to have formed by burial of the Dhiarizos Group rocks during subduction (Malpas et al. 1992; Chan et al. 2007).

The Dhiarizos Group is dominated by mafic extrusive rocks of the Phasoula and Loutra tis Aphroditis Formations. These extrusive rocks include two contrasting types, representing basement oceanic crust and seamounts built on that crust, respectively (Malpas et al. 1993). The first type is exemplified by widespread MORB-type tholeiitic lavas. These occur mainly as pillows with minor massive flows, breccias and hyaloclastites, and are intercalated with siliceous sediments of the Kholetria Member, and covered by radiolarian cherts and thin-bedded redeposited limestones and shales of the Late Jurassic-Early Cretaceous Mavrokolymbos Formation (Swarbrick \& Robertson 1980). The second type is represented by lesser amounts of WPB-type alkalic basaltic lavas and their derivatives (e.g. trachytes). These volcanic rocks mainly occur as pillow flows, sheet flows, breccias and dykes, and consist of a variety of lithologies, including aphyric basalts, feldspar ultraphyric basalts ( $>50 \mathrm{vol} \%$ feldspar), ankaramites and trachytes. In places, the aphyric basalts are seen to be rest upon the tholeiitic lavas and are overlain by the feldspar ultraphyric basalts. The alkalic lavas are closely associated with the reefoidal limestones of the Petra tou Romiou Formation (Swarbrick \& Robertson 1980; Malpas et al. 1993), from which Late Triassic calcareous fossils were recovered (Henson et al. 1949; Ealey \& Knox 1975). Norian radiolarians have been found within siliceous sediments of the Kholetria Member (Bragina 1998) and these clearly indicate the age of the volcanism to be Late Triassic.

In addition to volcanic rocks, minor intrusions of pyroxenite into the Dhiarizos Group volcanic rocks and lamprophyric dykes into the Ayios Photios Group sediments have been reported (Delaune- Mayere 1984; Malpas \& Xenophontos 1999). Delaune-Mayere (1984) was the first to recognize the presence of lamprophyres in SW Cyprus, but provided no detailed 
description. In the present study, a lamprophyre outcrop located to the south of Nata Village was examined. Field relations are unclear because of poor exposure, but the lamprophyre has a minimum size of $c .2 \mathrm{~m} \times 1 \mathrm{~m}$ and occurs alongside red mudstones of the Ayios Photios Group. The red mudstones are further interleaved between knockers of aphyric basalt and gabbro. It appears that the lamprophyre is probably either a dyke-like intrusion or a knocker in the mélange.

The lamprophyre is fresh, melanocratic and strongly porphyritic. It consists of abundant megaphenocrysts of amphibole (15-20\%), clinopyroxene (10-15\%) and olivine pseudomorphs (5-10\%), and microphenocrysts of biotite, melilite and titanite. Zoned brown pleochroic amphibole occurs as large, euhedral crystals, typically of the order of $20 \mathrm{~mm}$. Clinopyroxene forms large (up to $10 \mathrm{~mm}$ ) tabular and euhedral to subhedral crystals, and is typically zoned with brown rims and colourless cores. Olivine pseudomorphs, typically $0.2-1 \mathrm{~mm}$, are euhedral and wholly altered to serpentine at their rims and replaced by calcite at their cores. Biotite, titanite and melilite are found as $1 \mathrm{~mm}$ euhedral to subhedral microphenocrysts. The groundmass occupies c. $30-40 \%$ of the rock by volume, includes the same phases as the phenocrysts, and also incorporates opaque minerals, acicular apatite and analcite. Brown amphibole is the most abundant matrix phase, forming large euhedral to subhedral crystals. Magnetite grains are anhedral to subhedral, ranging from 0.02 to $1 \mathrm{~mm}$ in the groundmass, and occur as small inclusions in amphibole and olivine pseudomorphs. Acicular apatite $(c .0 .4 \mathrm{~mm})$ is also present in the groundmass, suggesting formation at a late (deuteric) stage. Rock (1991) suggested that the presence of primary amphibole and/or mica can be used as a criterion to distinguish lamprophyres from basanites and basalts, and it is appropriate to term the rocks under discussion here as alkaline lamprophyres (Rock 1991). Furthermore, the lack of feldspar and olivine in the groundmass suggests that they have close affinities with monchiquites.

\section{Geochemistry}

A total of 32 samples from the Dhiarizos Group volcanic and intrusive rocks were analysed for major and trace element concentrations. The results are available online at http:// www.geolsoc.org.uk/SUP18302. All analyses were carried out in the Department of Earth Sciences, The University of Hong Kong. Major element abundances were determined on fused glass pellets using a Phillips $2400 \mathrm{X}$-ray fluorescence (XRF) spectrometer. The trace elements $\mathrm{Sc}, \mathrm{V}, \mathrm{Cr}, \mathrm{Ni}, \mathrm{Cu}$ and $\mathrm{Zn}$ were also determined by XRF but on pressed powder pellets. Other trace elements, including REE, were analysed by inductively coupled plasma mass spectrometry (ICP-MS) on a VG PlasmaQuad III system. The protocol of Jenner et al. (1991) was used, with pure elemental standards for external calibration, and BHVO-1 as an internal reference material. Accuracies of the XRF analyses are estimated to be $\pm 2 \%$ for major elements and $\pm 5 \%$ for trace elements, whereas the ICP-MS analyses have accuracies of $\pm 5 \%$.

Earlier studies of the Late Triassic Dhiarizos Group volcanic rocks identified their alkalic and WPB-type characteristics (Lapierre 1968, 1975; Pearce 1975; Lapierre \& Rocci 1976; Swarbrick 1980), but Malpas et al. (1993) further identified two contrasting lava types based on detailed major and trace element work. One series consists of voluminous tholeiitic MORB and the other comprises transitional and alkalic WP basalts and their evolved products. On the basis of a limited number of samples, Lapierre et al. (2007) recently have argued that $\mathrm{Nd}$ isotopic ratios for the tholeiitic basalts do not resemble typical MORB and all Dhiarizos Group volcanic rocks are remnants of withinplate volcanoes. However, geochemical data from this study further substantiate the findings of Malpas et al. (1993), but one of the features of our dataset is that it shows that previously classified tholeiitic rocks can be further subdivided into two geochemical subtypes: MOR-tholeiites and ocean island tholeiites (OIT). Our data also provide the first geochemical information from the lamprophyres.

Lamprophyre is an important but relatively rare rock type that is not considered in the traditional total alkalis-silica (TAS) diagram. The identification of lamprophyres in this study is confirmed when two samples are plotted on the $\mathrm{MgO}-\mathrm{K}_{2} \mathrm{O}-$ $\mathrm{Al}_{2} \mathrm{O}_{3}$ diagram of Bergman (1987) (Fig. 4). Furthermore, these samples fall in the field of alkaline lamprophyres on the $\mathrm{CaO}-$ $\mathrm{MgO}$ diagram of Rock (1991) (Fig. 5). Chondrite-normalized REE patterns of all volcanic and intrusive rocks are shown in Figure 6. The tholeiites exhibit two prominent variable subgroups. The MOR-tholeiites display light REE (LREE)-depleted

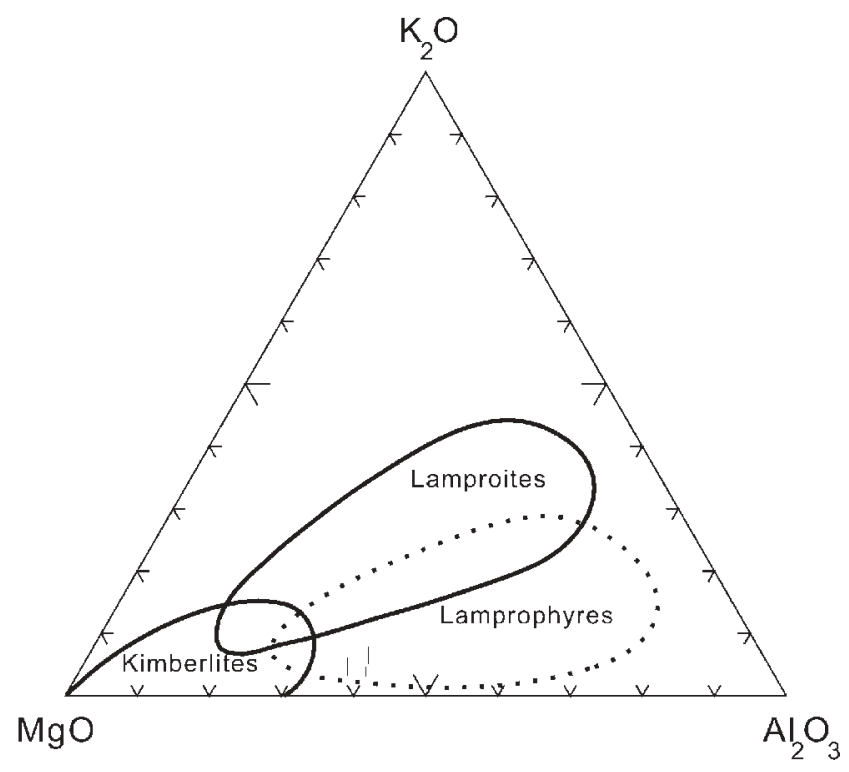

Fig. 4. Plot of lamprophyres from the current study on the $\mathrm{MgO}-\mathrm{K}_{2} \mathrm{O}-$ $\mathrm{Al}_{2} \mathrm{O}_{3}$ classification diagram of Bergman (1987).

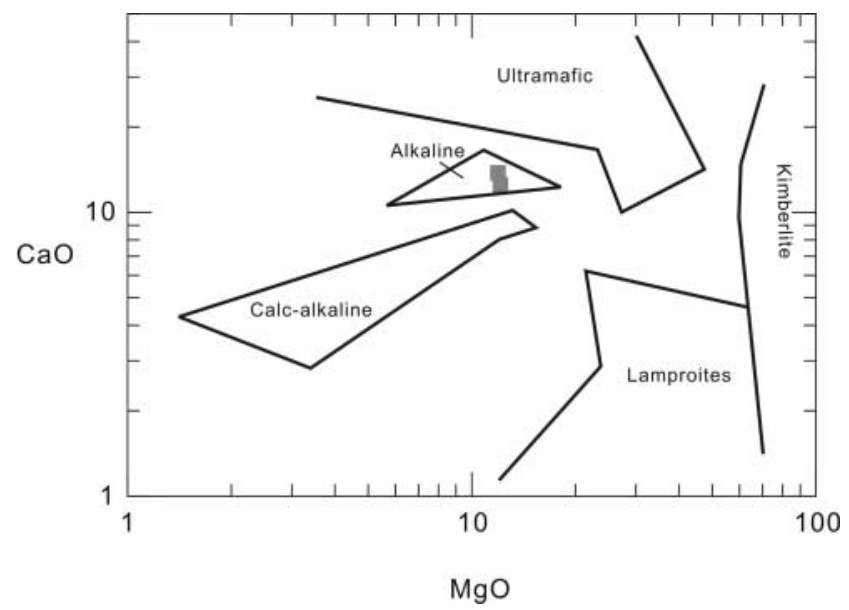

Fig. 5. Plot of lamprophyres from the current study on the classification plot of Rock (1991). 

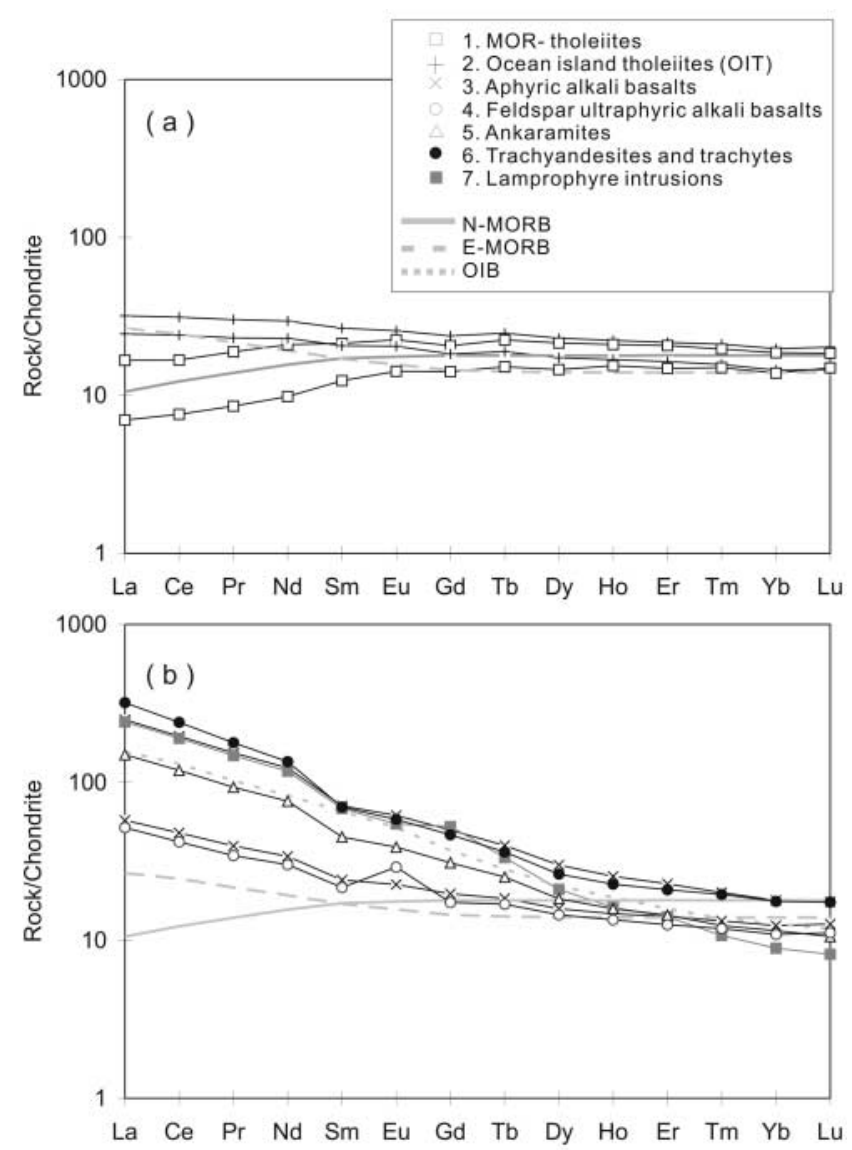

Fig. 6. Chondrite-normalized REE patterns of the Dhiarizos Group volcanic and intrusive rocks. Normalized OIB, N-MORB and E-MORB values are from Sun \& McDonough (1989). (a) Representative samples of MOR-type tholeiites and OIT. (b) Representative samples of alkaline varieties and lamprophyres.

and flat heavy REE (HREE) patterns whereas the OIT display LREE-enriched and flat HREE patterns. In addition, the OIT display an overall pattern similar to WP tholeiites. Conversely, the MOR-tholeiites exhibit LREE depletion similar to normal (N)-MORB. The REE patterns of all Dhiarizos Group alkalic volcanic rocks are LREE enriched, and the most fractionated samples have compositions comparable with OIB (ocean island basalt). The lamprophyres display a pattern representative of alkaline lamprophyres and enrichment in LREE. Concentrations of LREE ( $\mathrm{La}-\mathrm{Nd}$ ) are higher and those of HREE (Ho- $\mathrm{Lu}$ ) lower than for OIB. In addition, the lamprophyres show a pattern barely comparable with the most evolved alkalic varieties (i.e. trachytes). Figure 7 shows the N-MORB normalized trace element patterns for all groups. OIT show enrichment in large ion lithophile elements and the REE compared with N-MORB, and approximately the same concentrations of high field strength elements (HFSE) as average E-MORB. MOR-tholeiites have parallel patterns but with lower concentrations of all trace elements and REE. A few samples from both suites display peaks in Sr, suggesting plagioclase accumulation. All alkalic basalts are characterized by a general decrease in elemental abundance from $\mathrm{Th}$ to the HREE, showing troughs in $\mathrm{Sr}$ for some of the samples. The most fractionated aphyric alkalic basalts have similar compositions to average OIB. The feldspar ultraphyric
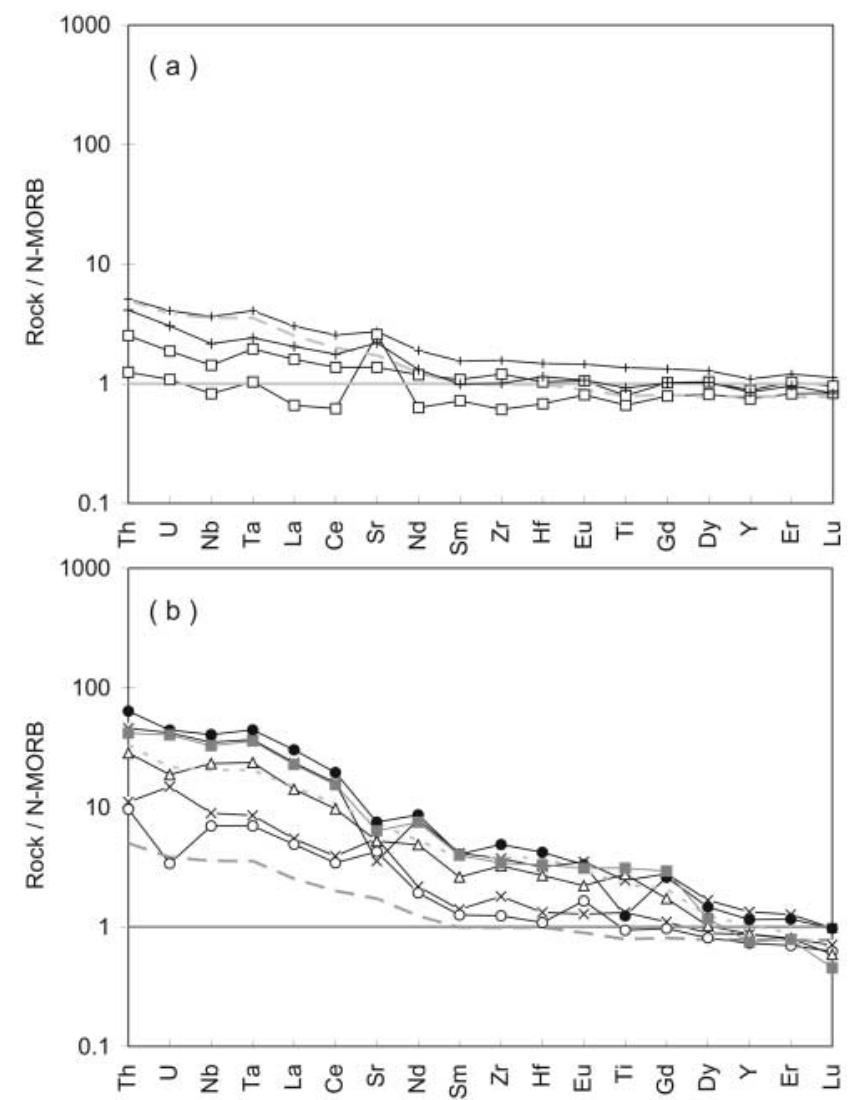

Fig. 7. N-MORB-normalized multi-element patterns of the Dhiarizos Group volcanic and intrusive rocks. Normalized OIB, N-MORB and E-MORB values are from Sun \& McDonough (1989). (a) Representative samples of MOR-type tholeiites and OIT. (b) Representative samples of alkaline varieties and lamprophyres. Symbols as in Figure 6.

basalts are roughly parallel to the aphyric alkalic basalts, but are shifted towards slightly lower mantle-normalized values. Exceptions are $\mathrm{Sr}$ and $\mathrm{Eu}$, which display positive spikes as a result of feldspar accumulation. Trachyandesites and trachytes have higher concentrations of trace elements than ankaramites and show significant troughs in $\mathrm{Sr}$ and $\mathrm{Ti}$, suggesting the removal of plagioclase and Ti-rich minerals. The last compositional group is lamprophyres, in which concentrations of La-Dy are higher and Ho-Lu lower than in OIB.

Discrimination between the MOR-tholeiites and OIT is clearly shown in the $\mathrm{Zr}-\mathrm{Nb}-\mathrm{Y}$ diagram of Meschede (1986) (Fig. 8). The alkalic rocks cluster in the field of WP alkalic and tholeiitic basalts whereas the OIT plot in the field of WP tholeiites. Further discrimination based on the immobile HFSE (Th-Hf-Ta) diagram of Wood (1980) shows that the Dhiarizos Group volcanic rocks and intrusive rocks consist of three subgroups. All alkalic volcanic rocks and alkaline lamprophyre intrusions plot in the alkaline WPB field, the OIT plot in the field of enriched (E)MORB-WP tholeiites (WPT) and the MOR-tholeiites fall within the field of N-MORB (Fig. 9). Overall, in the above discrimination diagrams, the MOR-tholeiites plot mainly in the field of MORB whereas the OIT plot in the field of either E-MORB or WPT. All alkalic rocks fall clearly within the field of WPB.

The Dhiarizos Group igneous rocks display a wide range of $\mathrm{La} / \mathrm{Sm}(0.9-11.5)$ and $\mathrm{Zr} / \mathrm{Nb}(2.7-31.0)$ ratios that cannot be explained by fractional crystallization alone because these 


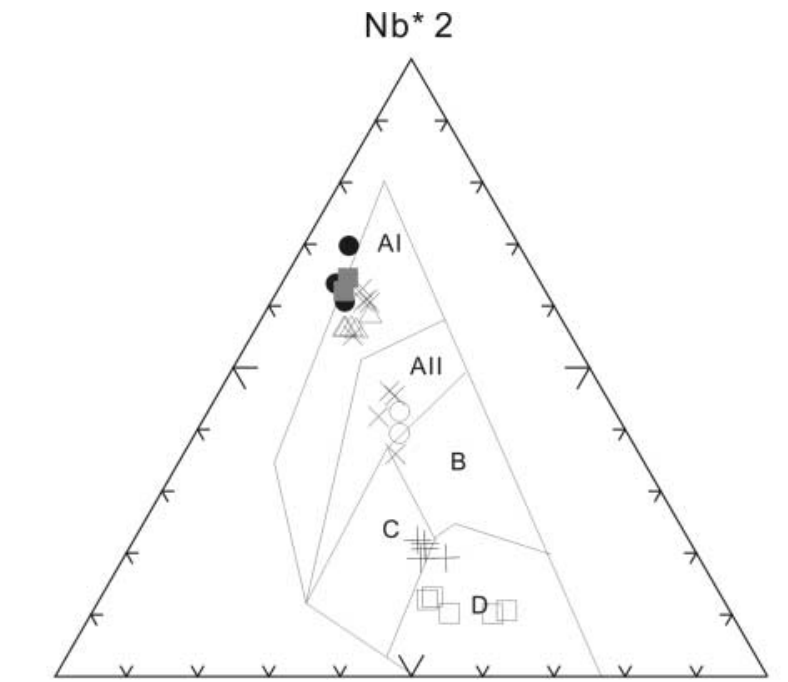

$\mathrm{Zr} / 4$

Y

\section{Al Within-plate alkali basalts All Within-plate alkali \& tholeiitic basalts B E-MORB \\ C Within-plate tholeiites \& volcanic arc basalts D N-MORB \& volcanic arc basalts}

Fig. 8. $\mathrm{Zr}-\mathrm{Nb}-\mathrm{Y}$ discrimination diagram of Meschede (1986). Symbols for all rocks from this study are as in Figure 6.

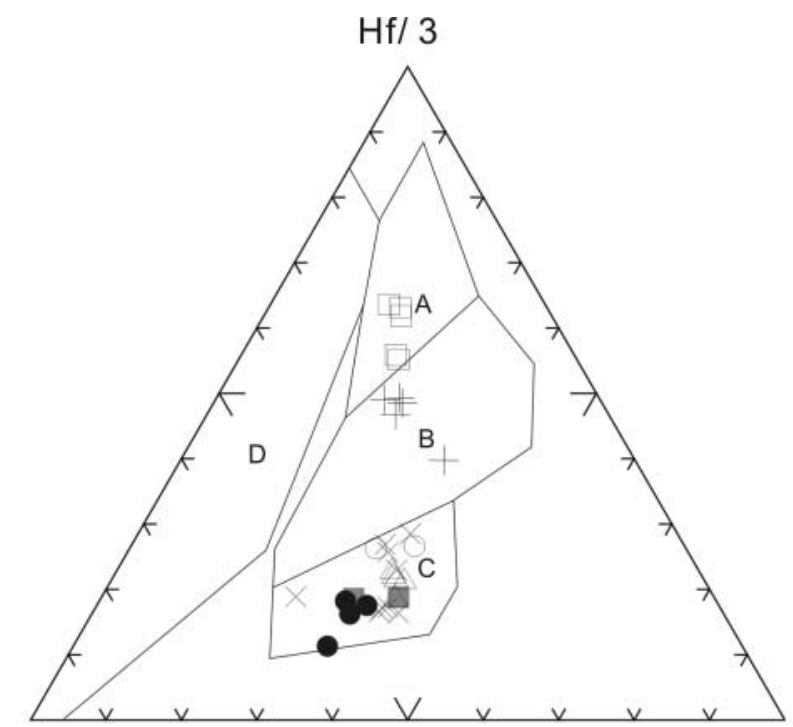

Th

$\mathrm{Ta}$

\section{A N-MORB \\ B E-MORB, within-plate tholeiites \\ C Alkaline within-plate basalts D Island arc \& calc alkaline arc tholeiites}

Fig. 9. Th-Hf-Ta discrimination diagram of Wood (1980). Symbols as for Figure 6. features are relatively insensitive to magmatic differentiation (Sun \& McDonough 1989). The range of variation may therefore be attributed to partial melting processes in the mantle source region. Semi-quantitative melt modelling was carried out to determine the source characteristics and their roles in the petrogenesis of the most primitive samples ( $\mathrm{MgO}>6.5 \mathrm{wt} \%)$. The melt models are presented in Figure 10, using point average, non-modal, batch melt modelling. Distribution coefficients of McKenzie \& O'Nions (1991) are used. Source compositions for depleted MORB mantle (DMM) are from Workman \& Hart (2005) and primitive mantle (PM) values are from Sun \& McDonough (1989). Batch melting curves for garnet and spinel lherzolite with a DMM composition are shown on a plot of $\mathrm{La} /$ $\mathrm{Yb}$ v. Sm/Yb (Fig. 10a). The MOR-tholeiites correlate well with the spinel lherzolite melting curve, suggesting that the samples may be the product of c. $3-10 \%$ partial melting. In contrast, most OIT samples plot away from the spinel lherzolite melting curve except sample AVP-44. The simplest model to account for this pattern involves mixing of small melt fractions from garnetfacies mantle with relatively larger melt fractions from spinelfacies mantle. A similar plot with a PM composition (Fig. 10b) shows that variable degrees of partial melting of spinel or garnet lherzolite cannot produce any MOR-tholeiites. Importantly, the plot indicates that both OIT and aphyric basalts are the products of variable degrees of partial melting of a spinel lherzolite (OIT c. $5-10 \%$; aphyric basalts $<1 \%$ ). An ankaramite sample plots in the intermediate position between the spinel and garnet lherzolite melting curves. This suggests that the sample might be a product of mixing of melt fractions from both the spinel and garnet field, implying that the melt originated from a deeper source when compared with OIT and aphyric basalts. The alkaline lamprophyres are consistent with c. $1-5 \%$ melting of a deep-seated garnet lherzolite source.

\section{Geochronology}

The majority of the Dhiarizos Group volcanic rocks are severely weathered and therefore not suitable for any radiometric dating. However, based on the field relationship with associated sediments, the age of the volcanic rock is inferred to be Late Triassic (Henson et al. 1949; Ealey \& Knox 1975; Bragina 1998). In the current study, amphibole separates from a fresh lamprophyric intrusion found near Nata Village in SW Cyprus were dated by the ${ }^{40} \mathrm{Ar}-{ }^{39} \mathrm{Ar}$ laser step-heating method. Amphibole grains were extracted from sample NAN-15 by handpicking and irradiated together with the LP-6 biotite standards (Odin et al. 1982) in the VT-C position for $30 \mathrm{~h}$ at the THOR reactor in Taiwan. After irradiation, standards were totally fused using double-vacuum resistant furnace and samples were incrementally heated using a US Laser Nd-YAG laser operated in continuous mode by changing laser output energy. The gas was analysed on a VG 3600 mass spectrometer at the National Taiwan University. Detailed analytical procedures have been outlined by Lo et al. (2002). The results of the ${ }^{40} \mathrm{Ar}-{ }^{39} \mathrm{Ar}$ laser step-heating experiments are plotted as age spectrum and isotope correlation diagrams in Figure 11 and all data are included in the Supplementary Publication (see page 702).

${ }^{40} \mathrm{Ar}-{ }^{39} \mathrm{Ar}$ laser step-heating experiments on the amphibole separate sample from NAN-15 yielded apparent dates of 127.3142.7 Ma with an integrated age of $139.5 \pm 0.4 \mathrm{Ma}$. In an age spectrum plot, these data show a flat profile with a plateau age of $140.7 \pm 0.4 \mathrm{Ma}$ over $87.3 \%$ of the total ${ }^{39} \mathrm{Ar}_{\mathrm{K}}$ released (Fig. 11a). Minor disturbances are found at the low-temperature steps, which are probably due to alteration effects. Regression of the 

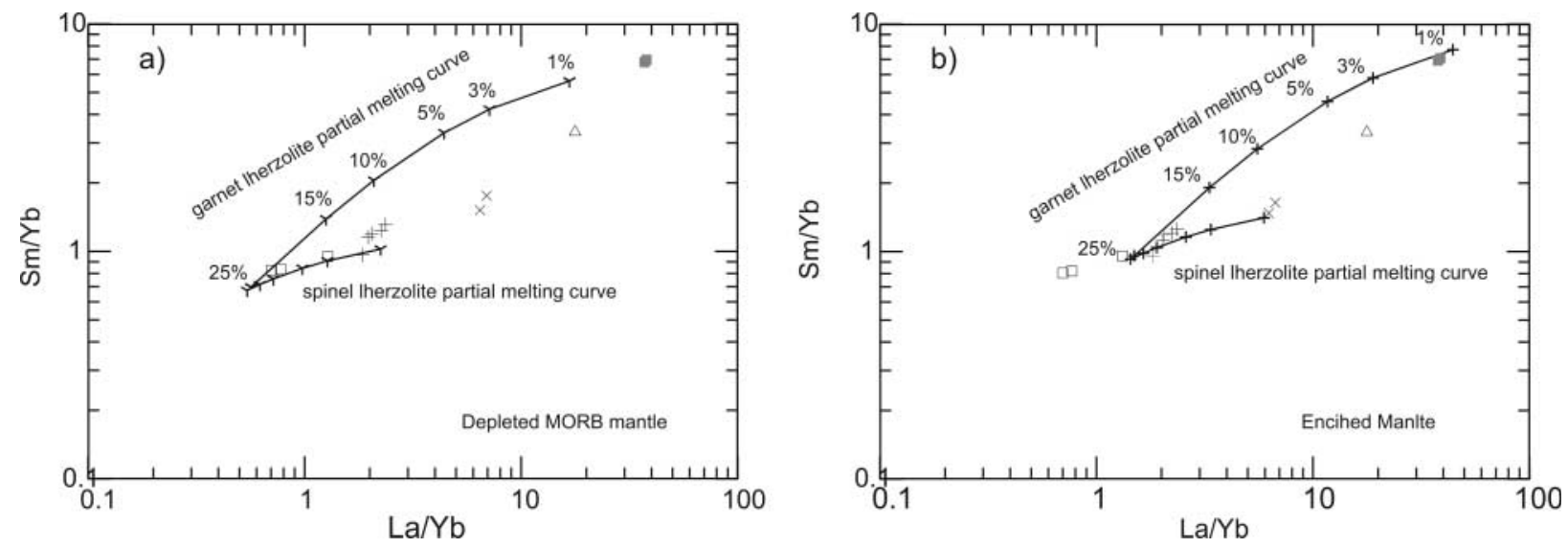

Fig. 10. Variation diagrams of $\mathrm{La} / \mathrm{Yb}$ v. Sm/Yb for the Dhiarizos Group magmatic rocks. Point-average, non-modal, batch melting curves for spinel and garnet lherzolites (garnet lherzolite is $59.8 \%$ ol, $21.1 \% \mathrm{opx}, 7.6 \% \mathrm{cpx}, 11.5 \%$ gt that melts in the proportions $5 \%$ ol, $20 \% \mathrm{opx}, 30 \% \mathrm{cpx}$, $45 \% \mathrm{gt}$; spinel lherzolite is $57.8 \% \mathrm{ol}, 27.0 \% \mathrm{opx}, 11.9 \% \mathrm{cpx}, 3.3 \%$ sp that melts in the proportions $10 \% \mathrm{ol}, 27 \% \mathrm{opx}, 50 \% \mathrm{cpx}, 13 \% \mathrm{sp}$; Thirlwall et al. 1994$)$. An additional spinel lherzolite is added to explain some intermediate condition: $8.4 \% \mathrm{cpx}, 65.5 \% \mathrm{ol}, 23.1 \% \mathrm{opx}$ and $3 \%$ gt. Distribution coefficients of McKenzie \& O’Nions (1991) are used. Source compositions for depleted MORB mantle (DMM) are from Workman \& Hart (2005) and primitive mantle (PM) values are from Sun \& McDonough (1989).
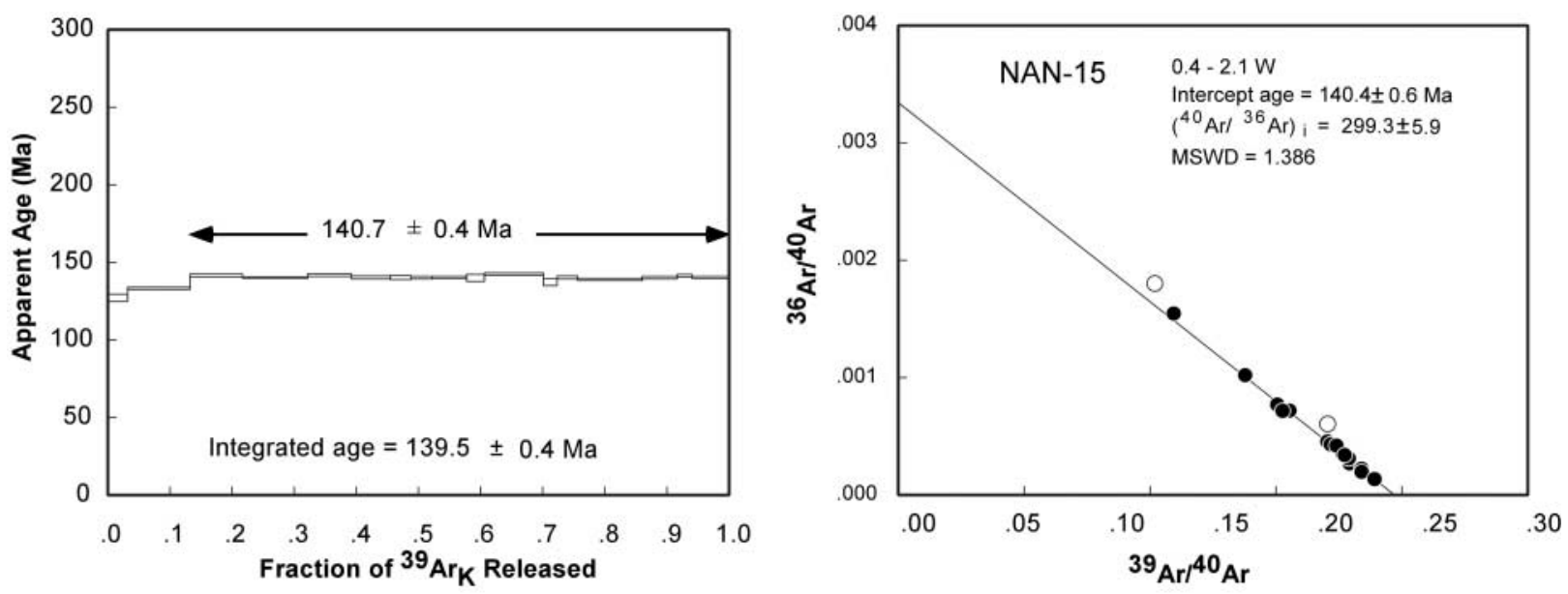

Fig. 11. (a) Apparent age spectrum and (b) ${ }^{36} \mathrm{Ar} /{ }^{40} \mathrm{Ar}-{ }^{39} \mathrm{Ar} /{ }^{40} \mathrm{Ar}$ isotope correlation diagram for amphibole separate from a lamprophyre intrusion.

data for the plateau steps yields an intercept age of $140.4 \pm 0.6 \mathrm{Ma}$ and ${ }^{40} \mathrm{Ar} /{ }^{36} \mathrm{Ar}$ initial value of $299.3 \pm 5.9$ with a mean square of the weighted deviation (MSWD) OF 1.386 (Fig. 11b). The intercept age, when considered against the data distribution and individual errors and the ${ }^{40} \mathrm{Ar} /{ }^{36} \mathrm{Ar}$ initial value, are in excellent agreement with the plateau age and the ratio of atmospheric Ar (295.5), respectively. In the present study, the measured, high-precision ${ }^{40} \mathrm{Ar}-{ }^{39} \mathrm{Ar}$ ages for the alkaline lamprophyre intrusions indicate formation at $140.7 \pm 0.4 \mathrm{Ma}$. Thus, these new ages suggest that Dhiarizos Group magmatism either consisted of at least two episodes (Late Triassic and Early Cretaceous) or spanned a considerable time period of perhaps $c$. $80 \mathrm{Ma}$, from Late Triassic to Early Cretaceous.

\section{Discussion}

\section{Geochemical characteristics of the Dhiarizos Group rocks}

On the basis of the trace element results and petrogenetic modelling described above, two types of tholeiites can be clearly distinguished in the Dhiarizos Group volcanic rocks. The MOR- type tholeiitic basalts resemble basalts erupted at an oceanic spreading centre and derived from a DMM source, whereas the OIT and other alkalic lavas are derived from enriched sources. The alkalic lavas are capped by Late Triassic reef limestones, as best seen at Petra tou Romiou, and have been interpreted as relict seamount volcanism (e.g. Malpas et al. 1993). Although a crosscutting relationship between the OIT and alkalic varieties was not observed in the field because of intense deformation and disintegration, we interpret both types of lavas as related to seamount volcanism. The OIT were formed during the shield stage of seamount construction, followed by the eruption of alkalic basalts, ankaramites and their evolved products in the post-shield stage. This evolution of the alkalic sequence chemistry can be explained by decrease of partial melting and fractional crystallization in shallow magma reservoirs with time, similar to present-day seamount examples (e.g. Hawaiian volcanoes, Floyd 1991).

Alkaline lamprophyre is not a common rock type, but it has been found in two different tectonic settings: on oceanic islands and in continental rifts (Rock 1991). For example, Furnes \& Stillman (1987) reported that alkaline lamprophyres form part 
of seamount magmatism; on the island of Maio in the Cape Verde archipelago, the basement complex representing oceanic crust is intruded by Middle Miocene alkaline lamprophyres and is further overlain by Late Miocene-Pleistocene volcanic rocks. The compositions of the alkaline lamprophyres and later volcanic rocks found on Maio are comparable and both suites are considered to be derived from the same parental magma source but modified to some extent by water trapped within the magma. Alkaline lamprophyres with similar composition and tectonic setting also occur on Gorringe Bank, SW Portugal (Cornen 1982) and on the Canary Islands (Ahijado et al. 2001). Although alkaline lamprophyres are found on oceanic islands, they are also typical of continental rifts. In Tamazert, Morocco, a variety of Mesozoic alkaline lamprophyres and associated intrusions cut limestone country rocks. These lamprophyres are interpreted to have been emplaced in a pull-apart basin associated with the opening of the Atlantic Ocean (Bouabdli et al. 1988; Bernard-Griffiths et al. 1991). Similarly, Mid-Proterozoic alkaline lamprophyres associated with rifting are described from Greenland (Brooks \& Platt 1975; Pearce \& Leng 1996).

In Cyprus, the composition of the Early Cretaceous alkaline lamprophyres is in contrast to the evolved Dhiarizos Group seamount volcanic rocks (i.e. the highly evolved alkalic basalts, trachytes and trachyandesite). As shown on the chondrite-normalized REE diagram (Fig. 6), certain LREE (La-Ce) and HREE $(\mathrm{Er}-\mathrm{Lu})$ contents of the lamprophyres are lower than those of the trachytes and trachyandesites. In addition, the Ti contents of alkaline lamprophyres are also higher than those of the most evolved alkalic varieties. REE melt modelling shows that that the lamprophyres are probably the product of melting of a garnet lherzolite whereas the alkalic lavas are derived from distinctly shallower sources. In addition, the lamprophyres are associated with terrigenous red mudstone of the Ayios Photios Group. This is somewhat difficult to reconcile with a seamount setting, as seamounts formed in an open ocean might be expected to be associated with carbonates and pelagic sediments, rather than terrigenous rocks (e.g. Floyd 1991).

To summarize, the igneous rocks from the Dhiarizos Group can be subdivided on the basis of geochemical characteristics as well as by age. The older group of rocks was formed in the Late Triassic, including MORB, WP-tholeiitic and alkalic basalts. The tectonic environments in which these rocks formed are thought to be due to the formation of MOR-type oceanic crust and associated seamount volcanism as proposed by Malpas et al. (1993). The latter event also involved the synchronous deposition of limestones, either as reefs or carbonate edifices or structures on and around the seamounts. The younger rocks are Early Cretaceous alkaline lamprophyres, which were probably formed in either a seamount or rift-related setting, although the latter is favoured. However, it is still uncertain if the Late Triassic and Early Cretaceous magmatism represent parts of a single longlived event or two independent events.

\section{Plate tectonic interpretation}

Combining the new information of the present study with the regional framework, a tectonic model is proposed for this part of the Neo-Tethyan oceanic basin that involves two phases of rifting. Initial rifting of the northern margin of Gondwanaland in the Late Triassic gave rise to a Neo-Tethyan oceanic basin (Lapierre 1968, 1975; Lapierre \& Rocci 1976). Evidence of riftrelated volcanism is seen in the Antalya Complex of SW Turkey (Juteau 1980; Robertson \& Woodcock 1982; Robertson \&
Waldron 1990; Dilek \& Rowland 1993). At the same time, an oceanic basin was formed to the south of the Kyrenia platform with the formation of MORB and seamount volcanic rocks of the Dhiarizos Group as described here and in previous studies (e.g. Malpas et al. 1993). Previous interpretations of the evolution of the Mamonia Complex assume an association of the Mamonia passive margin sequence with a micro-continental block. The original location of the Mamonia Block remains an open question. Some researchers have suggested that the Mamonia Block was detached from the northern margin of the southerly Neo-Tethyan oceanic basin (e.g. Robertson \& Woodcock 1979; Robertson 1998). Others have proposed that the Mamonia Block was simply part of the northern margin of Gondwanaland (e.g. Lapierre \& Parrot 1972; Moores et al. 1984). In the first interpretation, the tectonostratigraphy of the Mamonia Complex is considered to be readily comparable with the continental margin rocks of the Antalya Complex in SW Turkey. Robertson \& Woodcock (1982) showed that both the Mamonia and Antalya areas are dominated by terrigenous sediments, particularly during the Late Triassic and Late Jurassic-Early Cretaceous intervals. If the Mamonia Complex is interpreted to be part of the northern passive margin of the Neo-Tethys in the easternmost Mediterranean, it must have been detached and rotated together with the Troodos oceanic lithosphere during the Campanian-Eocene, and the Antalya Complex and its southward extension (Anaximander Seamounts) are probably the autochthonous remnants of the Mamonia Complex (Robertson et al. 2003). However, this hypothesis is difficult to evaluate when insufficient palaeomagnetic data are available from the Mamonia Complex (Clube et al. 1985; Clube \& Robertson 1986) to allow any meaningful tectonic interpretation. In the second model, the Mamonia Complex and Baer-Bassit mélange of NW Syria are considered to represent a continuous although disrupted geological belt that has similar passive margin sedimentary successions from the Late Triassic to at least the Early Cretaceous (Parrot 1977; Delaune-Mayere 1984). The extensive and long-lasting supply of sediments along the belt would suggest that the Mamonia Complex was part of a sizeable continent that could provide enough materials, and perhaps a micro-continental block did not separate from the northern margin of Gondwanaland until at least the second episode of rifting in the Early Cretaceous. However, it is to be noted that the Baer-Bassit mélange of NW Syria is characterized by redeposited carbonates from the Arabian margin (Al-Riyami et al. 2002) as opposed to the presence of Early Cretaceous quartzose sediments in the Mamonia Complex. The conundrum of the origin of the Mamonia Block perhaps can only be resolved when more data are available.

During the second episode of rifting, in the Early Cretaceous, the northern edge of Gondwanaland was thinned and intruded by rift-related rocks, including the alkaline lamprophyres of the Mamonia Complex. The lamprophyres observed in Nata occur alongside terrigenous mudstones, and Delaune-Mayere (1984) described additional lamprophyres interbedded with red mudstones elsewhere in SW Cyprus. As pointed out by Robertson (1990), the Mamonia Complex contains Early Cretaceous quartzose sandstones, suggesting that the lamprophyres formed within or adjacent to a continental margin. Deposition of manganiferious hydrothermal sediments of the Episkopi Formation also indicates the occurrence of volcanism at this time (Robertson \& Boyle 1983). This phase of renewed volcanism was probably not a localized event, as alkaline and peralkaline volcanic rocks are also present in the Baer-Bassit Complex of NW Syria (Parrot 1977; Delaune-Mayere 1984; Al-Riyami \& Robertson 2002). These basic volcanic rocks might be counterparts of the Early 
Cretaceous lamprophyres of the Mamonia Complex. In the Antalya Complex of SW Turkey, the presence of manganiferious hydrothermal sediments (Robertson \& Boyle 1983) and MORBtype volcanic rocks all indicate coeval volcanism (Yilmaz 1984; Robertson \& Waldron 1990; Dilek \& Rowland 1996). Widespread Late Jurassic-Early Cretaceous magmatism has been reported throughout the western edge of the Arabian subcontinent, extending from present-day Israel and Jordon, through Lebanon to central Syria (Garfunkel 1989, 1992; Laws \& Wilson 1997; Wilson et al. 2000, and references therein). Laws \& Wilson (1997) favoured a rift-related origin for this volcanism, but others (e.g. Garfunkel 1998) have argued that this interpretation is unlikely, as a major normal fault system of this age has never been detected onshore or offshore of the Levant using seismic methods. The latter researcher preferred that these volcanic rocks were formed in response to intraplate hotspot activity (Garfunkel 1989, 1992). Regardless of the origin of the Late Jurassic-Early Cretaceous volcanism in the Levant, it is evident that this phase of magmatism modified the basin adjacent to the Triassic margin and may even have involved the detachment of the Mamonia Block from the northern margin of Gondwanaland. The apparent small scale of Early Cretaceous alkalic magmatism in Cyprus may simply be a result of poor preservation, and other evidence of Early Cretaceous magmatism may have been destroyed during the collision of the Mamonia Complex and the Troodos oceanic lithosphere.

Our new results demonstrate the complexity of the geodynamic evolution of the southern Neo-Tethyan oceanic basin, with respect to its magmatic history. The two-phase rifting model, reminiscent of a similar model described by Robertson \& Woodcock (1979), places renewed emphasis on the episodic riftingdrifting history of the basin. A single long-lived spreading event from the Late Triassic through the Jurassic into the Early Cretaceous would have produced a massive ocean of a few thousand kilometres width; however, palaeomagnetic studies have never detected the existence of a substantial Mesozoic ocean (Morris 1996). Alternatively, a large oceanic basin could have been consumed along a subduction zone, but, as pointed out by Robertson \& Woodcock (1979), this would have produced an accretionary prism, for which there is no evidence in Cyprus or southern Turkey. It is more likely that only a little Jurassic oceanic crust was generated after the initial rifting and sea-floor spreading in the Late Triassic and, in the Early Cretaceous, riftrelated magmatism resumed and extended to sea-floor spreading locally, as seen in the Antalya Complex.

\section{Conclusions}

The Dhiarizos Group of the Mamonia Complex of SW Cyprus retains important evidence of Gondwanaland rifting and NeoTethyan oceanic basin development. Our results reveal that the Dhiarizos Group represents two episodes of magmatism. The main period of magmatism includes the formation of oceanic crust and associated seamount construction in the Late Triassic, and was followed by rift-related magmatism in the Early Cretaceous. The earlier phase of magmatism encompasses tholeiitic MOR oceanic crust and subalkalic and alkalic seamount varieties. The magmatism started with the eruption of MOR-type tholeiitic basalts, followed by OIT and other alkalic seamount varieties. The MOR-type tholeiites are derived from a DMM source and other seamount lavas are the products of variable degree of partial melting of a PM source. The later phase of magmatism is represented by alkaline lamprophyre intrusions that have ${ }^{40} \mathrm{Ar}-{ }^{39} \mathrm{Ar}$ ages of $140.7 \pm 0.4 \mathrm{Ma}$ and are linked to melting of a garnet lherzolite source. The configuration of the southern Neo-Tethyan oceanic basin was therefore largely controlled by a two-phase rifting-drifting process, occurring in the Late Triassic and Early Cretaceous intervals.

This work was supported by the Block Grant Earmarked for Research, The University of Hong Kong, to J. Malpas. F. Xiao and G. Ma are thanked for sample preparation. An earlier version of this paper benefited from the comments of S. Whattam. Y. Dilek and two anonymous reviewers are thanked for their constructive and helpful reviews.

\section{References}

Ahijado, A., Casillas, R. \& Hernandez-Pacheco, A. 2001. The dyke swarms of the Amanay Massif, Fuerteventura, Canary Islands (Spain). Journal of Asian Earth Sciences, 19, 333-345.

Al-Riyami, K. \& Robertson, A. 2002. Mesozoic sedimentary and magmatic evolution of the Arabian continental margin, northern Syria: evidence from the Baer-Bassit Mélange. Geological Magazine, 139, 395-420.

Al-Riyami, K., Danelian, T. \& Robertson, A.H.F. 2002. Radiolarian biochronology of Mesozoic deep-water successions in NW Syria and Cyprus: implications for south-Tethyan evolution. Terra Nova, 14, 271-280.

Bailey, S.W., Holdsworth, R.E. \& Swarbrick, R.E. 2000. Kinematic history of a reactivated oceanic suture: the Mamonia Complex Suture Zone, SW Cyprus. Journal of the Geological Society, London, 157, 1107-1126.

Ben-Avraham, Z. 1989. Multiple opening and closing of the eastern Mediterranean and south China basins. Tectonics, 8, 351-362.

Ben-Avraham, Z., Shoham, Y. \& Ginzburg, A. 1976. Magnetic anomalies in the eastern Mediterranean and the tectonic setting of the Eratosthenes Seamount. Geophysical Journal of the Royal Astronomical Society, 45, 105-123.

Ben-Avraham, Z., Ginzburg, A., Makris, J. \& Eppelbaum, L. 2002. Crustal structure of the Levant Basin, eastern Mediterranean. Tectonophysics, 346, $23-43$.

BERGMAN, S.C. 1987. Lamproites and other potassium-rich igneous rocks: a review of their occurrence, mineralogy and geochemistry. In: FITTON, J.G. \& UPTON, B.G.J. (eds) Alkaline Igneous Rocks. Geological Society, London, Special Publications, 30, 103-189.

Bernard-Griffiths, J., Fourcade, S. \& Dupuy, C. 1991. Isotopic study ( $\mathrm{Sr}, \mathrm{Nd}$ $\mathrm{O}$ and $\mathrm{C}$ ) of lamprophyres and associated dykes from Tamazert (Morocco): crustal contamination processes and source characteristics. Earth and Planetary Science Letters, 103, 190-199.

Bouabdi, A., Dupuy, C. \& Dostal, J. 1988. Geochemistry of Mesozoic alkaline lamprophyres and related rocks from the Tamazert massif, High Atlas (Morocco). Lithos, 22, 43-58.

Bragina, N.Y. 1998. Radiolarian biostratigraphy of the Mamonia Complex, southwestern Cyprus. In: Panayides, I. \& Xenophontos, C. (eds) Proceedings of the Third International Conference on Geology of the Eastern Mediterranean. Geological Survey Department, Nicosia, 10.

Brooks, C.K. \& PlatT, R.C. 1975. Kaersutite-bearing gabbroic inclusions and the late dike swarm of Kangerdlugssuaq, East Greenland. Mineralogical Magazine, 40, 258-283.

Chan, G.H.-N., Malpas, J.G., Xenophontos, C. \& Lo, C.-H. 2007. Timing of subduction zone metamorphism during the formation and emplacement of Troodos and Baer-Bassit ophiolites: insights from ${ }^{40} \mathrm{Ar}-{ }^{39} \mathrm{Ar}$ geochronology. Geological Magazine, 144, 797-810.

Clube, T.M. \& Robertson, A.H.F. 1986. The palaeorotation of the Troodos microplate, Cyprus, in the Late Mesozoic-Early Cenozoic plate tectonic framework of the Eastern Mediterranean. Surveys in Geophysics, 8, 375-434.

Clube, T.M., Creek, K.M. \& Robertson, A.H.F. 1985. Palaeorotation of the Troodos microplate, Cyprus. Nature, 317, 522-525.

CoRnen, G. 1982. Petrology of the alkaline volcanism of Gorringe Bank (southwest Portugal). Marine Geology, 47, 101-130.

Delaune-Mayere, M. 1984. Evolution of a Mesozoic passive continental margin: Baer-Bassit (NW Syria). In: Dixon, J.E. \& Robertson, A.H.F. (eds) The Geological Evolution of the Eastern Mediterranean. Geological Society, London, Special Publications, 17, 151-159.

Dercourt, J., Zonenshain, L.P. \& Ricou, L.P. et AL. 1986. Geological evolution of the Tethys belts from the Atlantic to the Pamirs since the Lias. Tectonophysics, 123, 241-315.

DileK, Y. \& Moores, E.M. 1990. Regional tectonics in the eastern Mediterranean ophiolites. In: Malpas, J., Moores, E.M., Panayiotou, A. \& XenophonTos, C. (eds) Ophiolites: Oceanic Crustal Analogues. Proceedings of the Symposium, 'Troodos 1987'. Geological Survey Department, Nicosia, 295309.

DileK, Y. \& Rowland, J.C. 1993. Evolution of a conjugate passive margin pair in 
Mesozoic Southern Turkey. Tectonics, 12, 954-970.

EALey, P.J. \& KNOX, G.J. 1975. The pre-Tertiary rocks of S.W. Cyprus. Geologie en Mijnbouw, 54, 85-100.

FLoYd, P.A. 1991. Oceanic Basalts. Blackie, Glasgow.

Furnes, H. \& Stillman, C.J. 1987. The geochemistry and petrology of an alkaline lamprophyre sheet intrusion complex on Maio, Cape Verde Republic. Journal of the Geological Society, London, 144, 227-241.

GarfunKel, Z. 1989. Tectonic setting of Phanerozoic magmatism in Israel. Israel Journal of Earth Sciences, 38, 51-74.

GarfunKel, Z. 1992. Darfur-Levant array of volcanics: a 140-Ma-long record of a hot spot beneath African-Arabian continent, and its bearing on Africa's absolute motion. Israel Journal of Earth Sciences, 40, 135-150.

GaRfunKel, Z. 1998. Constrains on the origin and history of the Eastern Mediterranean basin. Tectonophysics, 298, 5-35.

Henson, F.R.S., Browne, R.V. \& McGinty, J. 1949. A synopsis of the stratigraphy and geological history of Cyprus. Journal of the Geological Society, London, 105, 1-41.

Jenner, G.A., Dunning, G.R., Malpas, J., Brown, M. \& Brace, T. 1991. Bay of Islands and Little Port complexes, revisited: age, geochemical and isotopic evidence confirm suprasubduction-zone origin. Canadian Journal of Earth Sciences, 28, 1635-1652.

Juteau, T. 1980. Ophiolites of Turkey. Ofioliti, 2, 199-317.

Kohn, B.P., LANG, B. \& Steinitz, G. $1993 .{ }^{40} \mathrm{Ar}{ }^{39} \mathrm{Ar}$ dating of the Atlit-1 volcanic sequence, northern Israel. Israel Journal of Earth Sciences, 42, $17-28$

LAPIERRE, H. 1968. Découverte d'une série volcanosédimentaire probablement d'âge Crétacé supérieur au S-W de l'île de Chypre. Comptes Rendus de l'Académie des Sciences, 266, 1817-1820.

LAPIERRE, H. 1975. Les formations sedimentaires et eruptives des nappes de Mamonia et leurs relations avec le massif du Troodos (Chypre occidentale). Memoires de la Société Géologique de France, 54, 123.

Lapierre, H. \& Parrot, J.F. 1972. Identité géologique des regions Paphos (Chypre) et du Baer-Bassit (Syrie). Comptes Rendus de l'Académie des Sciences, 274, 1999-2002.

LapierRe, H. \& Rocci, G.M. 1976. Un bel exemple d'association cogénétique laves-radiolarites-calcaires: la formation triasique de Pétra tou Romiou (Chypre). Comptes Rendus de l'Académie des Sciences, 268, 2637-2640.

Lapierre, H., Bosch, D., Narros, A., Mascle, G.H., Tardy, M. \& Demant, A. 2007. The Mamonia Complex (SW Cyprus) revisited: remnant of Late Triassic intra-oceanic volcanism along the Tethyan southwestern passive margin. Geological Magazine, 144, 1-19.

Laws, E.D. \& WILSON, M. 1997. Tectonics and magmatism associated with Mesozoic passive continental margin development in the Middle East. Journal of the Geological Society, London, 154, 459-464.

Le Pichon, X. 1982. Land-locked oceanic basins and continental collision: the Eastern Mediterranean as a case example. In: Hsu, K.J. (ed.) Mountain Building Processes. Academic Press, New York, 201-211.

Lo, C.-H., Chung, S.-L., Lee, T.-Y. \& Wu, G.-Y. 2002. Age of the Emeishan flood magmatism and relations to Permian-Triassic boundary events. Earth and Planetary Science Letters, 198, 449-458

Malpas, J. \& Xenophontos, C. 1999. Geological Map of the Ayia VarvaraPentalia Area. Scale 1:25 000. Geological Survey Department, Nicosia.

Malpas, J., Xenophontos, C. \& Williams, D. 1992. The Ayia Varavara Formation of S.W. Cyprus, a product of complex collisonal tectonics. Tectonophysics, 212, 193-211.

Malpas, J., Calon, T. \& Squires, G. 1993. The development of a late Cretaceous microplate suture zone in SW Cyprus. In: Prichard, H.M., Alabaster, T., Harris, N.B.W. \& Neary, C.R. (eds) Magmatic Processes and Plate Tectonics. Geological Society, London, Special Publications, 76, 177-195.

Markis, J., Ben-Avraham, Z. \& Behle, A. et al. 1983. Seismic refraction profiles between Cyprus and Israel and their interpretation. Geophysical Journal of the Royal Astronomical Society, 75, 575-591.

McKenZie, D. \& O'Nions, R.K. 1991. Partial melt distribution from inversion of rare earth element concentrations. Journal of Petrology, 32, 1021-1091.

Meschede, M. 1986. A method of discriminating between different types of midocean ridge basalts and continental tholeiites with $\mathrm{Nb}-\mathrm{Zr}-\mathrm{Y}$ diagram. Chemical Geology, 56, 207-218.

Moores, E.M., Robinson, P.T., Malpas, J. \& Xenophontos, C. 1984. Model for the origin of the Troodos massif, Cyprus, and other Mideast ophiolites. Geology, 12, 500-503.

MoRRIS, A. 1996. A review of palaeomagnetic research in Troodos ophiolite, Cyprus. In: Morris, A. \& TARLing, D.H. (eds) Palaeomagnetism and Tectonics of the Mediterranean Region. Geological Society, London, Special Publications, 105, 311-324.

Odin, G.S., AdAms, C.J., Armstrong, R.L. ET AL. 1982. Interlaboratory standards for dating purposes. In: Odin, G.S. (ed.) Numerical Dating in Stratigraphy. Wiley, Chichester, 123-149.

Papazachos, B.C. \& Papaionnnou, Ch.A. 1999. Lithospheric boundaries and plate motions in the Cyprus area. Tectonophysics, 308, 193-204

Parrot, J.F. 1977. Assemblage ophiolitique du Baër-Bassit et termes effusifs du volcano-sédimentaire. Travaux et Documents de l'ORSTOM, 72.

Pearce, J.A. 1975. Basalt geochemistry used to investigate past tectonic environments on Cyprus. Tectonophysics, 25, 41-67.

Pearce, N.J.G. \& LenG, M.J. 1996. The origin of carbonatites and related rocks from the Igaliko Dyke Swarm, Gardar Province, South Greenland: filed, geochemical and $\mathrm{C}-\mathrm{O}-\mathrm{Sr}-\mathrm{Nd}$ isotope evidence. Lithos, 39, 21-40.

RoberTson, A.H.F. 1977. The Kannaviou, Cyprus: volcaniclastic sedimentation of a probable Late Cretaceous arc. Journal of the Geological Society, London, $133,447-466$.

Robertson, A.H.F. 1990. Tectonic evolution of Cyprus. In: Malpas, J., Moores, E.M., Panayiotou, A. \& Xenophontos, C. (eds) Ophiolites: Oceanic Crustal Analogues. Proceedings of the Symposium, 'Troodos 1987'. Geological Survey Department, Nicosia, 235-250.

RoberTson, A.H.F. 1998. Mesozoic-Tertiary tectonic evolution of the Easternmost Mediterranean area: integration of marine and land evidence. In: ROBERTSON, A.H.F., Emeis, K.-C., Richter, C. \& Camerlenghi, A. (eds) Proceedings of the Ocean Drilling Program, Scientific Results, 160. Ocean Drilling Program, College Station, TX, 723-782.

Robertson, A.H.F. \& Boyle, J.F. 1983. Tectonic setting and origin of metalliferous sediments in the Mesozoic Tethys. In: Rona, P.A. Bostroem, K, Laubier, L. et AL. (ed.) Hydrothermal Processes at Seafloor Spreading Centres. NATO Conference Series, 595-663.

Robertson, A.H.F. \& MART, Y. 1998. Eratosthenes Seamount: an oceanographic yardstick recording the Late Mesozoic-Tertiary geological history of the Eastern Mediterranean. In: Robertson, A.H.F., EMeIS, K.-C., Richter, C. \& Camerlenghi, A. (eds) Proceedings of the Ocean Drilling Program, Scientific Results, 160. Ocean Drilling Program, College Station, TX, 701708 .

ROBERTSON, A.H.F. \& WALDRON, J.W.F. 1990. Geochemistry and tectonic setting of Late Triassic and late Jurassic-Early Cretaceous basaltic extrusives from the Antalya Complex, SW Turkey. In: Savascin, M.Y. \& ERonat, A.H. (eds) Proceedings of International Earth Sciences Congress on Aegean Region. Dokuz Eylul University, Izmir, 2, 279-299.

Robertson, A.H.F. \& WoodCock, N.H. 1979. Mamonia Complex, southwest Cyprus, Evolution and emplacement of a Mesozoic continental margin. Geological Society of America Bulletin, 90, 651-665.

Robertson, A.H.F. \& WoODCoCK, N.H. 1982. Sedimentary history of the southwestern segment of the Mesozoic-Tertiary Antalya continental margin, south-western Turkey. Eclogae Geologicae Helvetiae, 75, 517-562.

Robertson, A.H.F., Kidd, R.B., Ivanov, A.F., Limonov, A.F., Woodside, J.M., Galindo-Zaldivar, J. \& Nieto, K. 1995. Eratosthenes Seamount: collisional processes in the easternmost Mediterranean in relation to the PlioQuaternary uplift of southern Cyprus. Terra Nova, 7, 254-264.

Robertson, A.H.F., PoIsson, A. \& AKINCI, Ö. 2003. Developments in research concerning Mesozoic-Tertiary Tethys and neotectonics in the Isparta Angle, SW Turkey. Geological Journal, 38, 195-234.

Rock, N.M.S. 1991. Lamprophyres. Blackie, Glasgow.

Sun, S.-S. \& McDonough, W.F. 1989. Chemical and isotopic systematics of oceanic basalts: implications for mantle composition and processes. In: SAUnders, A.D. \& NoRry, M.J. (eds) Magmatism in the Ocean Basins. Geological Society, London, Special Publications, 42, 313-345.

Swarbrick, R.E. 1980. The Mamonia Complex of SW Cyprus and its relationship with the Troodos complex. In: Panayiotou, A. (ed.) Ophiolites. Proceedings of the Interantional Ophiolite Symposium, 1979. Geological Survey Department, Nicosia, 86-92.

Swarbrick, R.E. 1993. Sinistral strike-slip and transpressional tectonics in an ancient ocean setting: the Mamonia Complex, southwest Cyprus. Journal of the Geological Society, London, 150, 381-392.

SWARbrick, R.E. \& RoberTson, A.H.F. 1980. Revised stratigraphy of the Mesozoic rocks of southern Cyprus. Geological Magazine, 117, 547-563.

Thirlwall, M.F., Upton, B.G.J. \& Jenkins, C. 1994. Interaction between continental lithosphere and the Iceland Plume $-\mathrm{Sr}-\mathrm{Nd}-\mathrm{Pb}$ isotope geochemistry of Tertiary basalts, NE Greenland. Journal of Petrology, 35, 839-879.

URquHART, E. \& BANNER, F.T. 1994. Biostratigraphy of the supra-ophiolite sediments of the Troodos Massif, Cyprus: the Cretaceous Perapedhi, Kannaviou, Moni and Kathikas Formations. Geological Magazine, 131, 499-518.

VerZhitssky, E.V. 1996. The Geothermal Regime and Seafloor Tectonics of Marine Basins along the Alpine-Himalayan Belt. Nauka, Moscow [in Russian].

Wilson, M., Shimron, A.E., Rosenbaum, J.M. \& Preston, J. 2000. Early Cretaceous magmatism of Mount Hermon, Northern Israel. Contributions to Mineralogy and Petrology, 139, 54-67.

Wood, D.A. 1980. The application of a Th-Hf-Ta diagram to problems of tectonomagmatic classification and to establishing the nature of crustal contamination of basaltic lavas of the British Tertiary volcanic province. 
Earth and Planetary Science Letters, 50, 11-30.

Woodside, J.M. 1977. Tectonic elements and crust of the eastern Mediterranean. Marine Geophysical Researches, 3, 317-354.

Workman, R.K. \& HART, S.R. 2005. Major and trace element composition of the depleted MORB mantle (DMM). Earth and Planetary Science Letters, 231,
53-72.

Yilmaz, P.O. 1984. Fossil and K-Ar data for the age of the Antalya Complex, SW Turkey. In: Dixon, J.E. \& Robertson, A.H.F. (eds) The Geological Evolution of the Eastern Mediterranean. Geological Society, London, Special Publications, 17, 335-348.

Received 23 March 2007; revised typescript accepted 4 October 2007.

Scientific editing by Alan Collins 